Afrika Focus, Vol. 8, Nr. 3-4, 1922, pp. 202-214

\title{
THE NATURAL ENVIRONMENT OF THE NAMIB DESERT
}

\section{Patrick VAN DAMME \& Patrick VERNEMMEN}

Laboratory for Tropical and Sub-tropical Agronomy and Ethnobotany

Faculty of Agricultural and Applied Biological Sciences

Coupure Links, 653

B-9000 Gent BELGIUM

\section{SUMMARY}

The Topnaar basically live in two distinct areas in the Namib Desert i.e. the Kuiseb river valley and the Sesfontein area. The ecology of both these zones is presented and discussed in detail. Specific attention is given to the plant communities that occur in both of them.

\section{Introduction}

In this article, the living environment of the Topnaar people will be presented and discussed. Most findings are based on literature data and personal observations by the authors.

The Topnaar basically live along the Kuiseb river, one of the seasonal rivers that flow in the Namib Desert. It forms the border between the northern stone desert and the southern sand dune sea. A second Topnaar community lives in Sesfontein, a village about $500 \mathrm{~km}$ north of the Kuiseb. Sesfontein is situated just outside the Namib, in the pro-Namib, the more humid area east of the Namib (see map 1).

\section{Natural Environment in the Kuiseb Area}

The residential area of the Topnaar of the Kuiseb valley is limited to a number of settlements in the lowest part of the Kuiseb. Communities are situated along the linear oasis which is the Kuiseb's riverbed. South of the river the sand sea of the Southern Namib extends towards Lüderitz. North 
of the river the gravel plain of the Central Namib, strewn with a number of mountains, extends towards the Ugab.

\subsection{Climate}

The climate of the Namib is characterized by a low and very variable rainfall, an evaporation that exceeds precipitation, high insolation, cool to extremely high temperatures and the frequent occurrence of fog and stratus clouds.

The climate is strongly influenced by the Benguela Current, a branch of the Westerly Wind Drift Current. The Benguela Current flows northwards along the south-west coast of Africa. Along the western margin of the Benguela Current part of the surface water flows westwards into the Atlantic Ocean and is replaced by upwelling cold bottom water from the Antarctic Intermediate Current. The result is a mass of cold water along the coast with a mean annual sea temperature of about $15^{\circ} \mathrm{C}$. This current of cold water is one of the major reasons for the aridity of the Namib. The anticyclone of the south Atlantic Ocean causes movement of warm air towards the west coast of Southern Africa. There it comes in contact with the cooled air above the Benguela Current resulting in condensation of moisture, producing fog. Inland, strong insolation results in low pressure cells, producing sea-breezes. As the cool, moist air comes inland it is warmed and relative humidity decreases. During the night when the temperature inland drops dramatically a reverse situation is created: dry, cool land-breezes predominate. The overall result is a nearly continuous high relative humidity along the coast and inland a decreasing relative humidity with increasing distance from the sea.

Fog and low stratus clouds are very common and extend sometimes more than $50 \mathrm{~km}$ inland. The condensation of the water, originating from fog and low stratus clouds, on plants is the most important water source for these plants in the coastal belt and on the mountain ranges up to about $50 \mathrm{~km}$ from the coast.

Precipitation by rain is very low. The reason is that due to the cool ocean water a strong, stable temperature inversion is created (immediately above the surface a layer of cool air is formed due to the cooling effect of the ocean water; above this layer the air has the normal (high) temperature, whereas normally temperature decreases with increasing height). Circulation of the air around the anticyclone of the South Atlantic leads to a flow of air more or less parallel to the coast. The cool, moist air is warmed up when entering the warm land, resulting in an increase of the water holding capacity of the 
air. Every drop of water evaporates and rain cannot occur in such conditions. The influence of this climatic system decreases with increasing distance from the sea. As a result the amount of rain increases along this gradient.

Temperatures along the coast are cool and show little diurnal variation, due to the influence of the cold sea water and the frequent occurrence of fog and/or stratus clouds. Inland, maximum temperatures increase (up to more than $40^{\circ} \mathrm{C}$ ) with distance from the sea. Sometimes a strong warm anticyclone is situated on the central plateau of Southern Africa. This air mass can then descend towards the coast. As a result of increased atmospheric pressure, adiabatic heating (without adding or reducing heat) occurs and results in strong, extremely hot and dry winds (the dreaded "east" or "berg winds").

The full establishment of the Benguela Current and its associated cold water upwelling system in the Late Miocene (somewhat over 5 million years ago) promoted the development of the current Namib Desert Regime. During the Quaternary, the level of the riverbed of the Kuiseb varied a lot, depending on the climatic conditions; the course of the Kuiseb also changed. In the beginning of the Quaternary, the Kuiseb course extended from the Klein Klipneus/Klipneus area westwards to the northern half of Sandwich Bay. Later on during the Quaternary the course of the lower Kuiseb shifted towards the north. Subsequently, a delta was formed, south of Walvisbay. This displacement may have been caused primarily by the northward encroachment of dunes from the main Namib sand sea. The shift in the lower course was only possible because here the Kuiseb did not flow in a canyon but rather in a broad valley with low banks.

\subsection{Geography and Geology}

In the Kuiseb area, the following geographical and geological entities can be recognized:

\subsubsection{River Valley of the Kuiseb}

The Kuiseb is the largest and most important river of the Central Namib. It has a large catchment area $\left(14,700 \mathrm{~km}^{2}\right)$ which extends for a great deal over the moutainous area of Khomas Hochland, a zone with an annual rainfall of about $300 \mathrm{~mm}$. Its source can be found near Windhoek. About $230 \mathrm{~km}$ downstream it leaves Khomas Hochland and enters a canyon that is about $130 \mathrm{~km}$ long. Nearly every year floods pass through the narrow canyon. Near Homeb the depth of the canyon decreases while the riverbed widens. About $50 \mathrm{~km}$ downstream from Homeb, the riverbed is more than $1.5 \mathrm{~km}$ wide. 
Downstream from Rooibank, at about $27 \mathrm{~km}$ from the coast, a bifurcation of the riverbed is caused by a granite outcrop. The southern branch goes westerly towards the coast. This branch has, with time, been nearly completely overblown by dunes and as a result the superficial flowing water of the Kuiseb can not reach the sea. The subterranean waterflow, however, is still sufficient to support plant growth. Large parts of this area form the main !nara field, used by the Kuiseb Topnaar. The northern arm once formed a very wide delta which reached the ocean at Walvisbay Lagoon. Since 1837 the river has reached the coast only 15 times. Due to the building of a 7.3 $\mathrm{km}$ long flood retaining dam in the early sixties to protect Walvisbay, no superficial water can now enter this northern arm. As the dam is built on a granite subsoil, also the subterranean water flow is blocked. This has resulted in a steady deterioration of the vegetation, including the !nara fields in this area over the last 3 decades.

The Kuiseb forms the northern border of the Southern Namib dune sea. A study of the wind regime and its related sand dune movement has revealed that to the west of Rooibank there is a high-energy, dominantly SSW wind regime while inland from Rooibank a low to intermediate energy, complex wind regime occurs. Generally a SSW to SW wind predominates in summer, while during winter, east winds that have a high velocity but low frequency occur. This results in the net movement of dune sand in a NNE - NE direction into the Kuiseb. The greatest rates of movement are measured west of Rooibank. Between Rooibank and Swartbank the movement is limited by both large stands of Stipagrostis sabulicola (PILGER) DE WINTER (Poaceae) and the wind regime.

The occasional flooding of the Kuiseb is probably the most important factor in checking the migration of the dunes. The floods transport huge amounts of silt and sand from both upstream and the dunes that have moved into the riverbed. However, due to evaporation, lower rainfall, drainage through the soil of the riverbed and the smaller gradient of the river, the energy and quantity of flood water decreases towards the coast. As a result, floods usually end somewhere in the lower Kuiseb.

The effect of these floods is of considerable importance for the ecosystem. Sand, blown into the riverbed from the dunes, is scoured away, preventing the dunes from crossing the Kuiseb and advancing northwards onto the gravel plain of the Central Namib. A large amount of fruit and seed material coming from Khomas Hochland and other areas are transported, germinate and thus enrich the flora of the valley. The subterranean water supply, which maintains the riverine woodland on the riverbanks, is replenished. On the other hand, 
the colonization of the riverbed by trees and other perennials is restricted because floods uproot and wash away virtually all plants hit by the stream of water.

The drought conditions that have been in existence since the beginning of the eighties, and the construction of many farm dams on the tributaries of the Kuiseb have reduced the number and the strength of floods considerably. Together with the dominant high-energy SSW-SW winds, this allows the Southern Namib sand sea to cross the Kuiseb west of Rooibank.

In the eastern part of the Kuiseb area the Kuiseb formation (Damara sequence, late Precambrium) is the main exposed lithographic unit. In this area schists are the most abundant geological formation (e.g. Khomas Hochland, Kuiseb Canyon). Parts of the Kuiseb formation (especially in the western part of the Kuiseb area) are covered with recent layers of sand, gravel, calcrete and alluvium of the Cenozoicum (Tertiary and Quaternary).

\subsubsection{Gravel Plain of the Central Namib}

The gravel plain of the Central Namib covers a vast area north of the Kuiseb. The altitude of the plain gradually increases from the coast towards the east (up to 800-900 m) and in several places granite mountains (inselbergs or bornhardts) occur. In the west there exists a calcrete mountain range (Swartbankberg-Hamiltonberge-Witpoortberge). On the plain itself numerous washes form small depressions in which some water accumulates after a rain shower, sufficient to maintain a vegetation different from that which occurs on the rest of the plain.

As in the Kuiseb area, the gravel plain is covered by Cenozoic layers of sand, gravel, etc....

\subsubsection{Coastal Plain, South of Walvisbay}

In the Walvisbay area between the coastal dune row and the dunes which cross the Kuiseb there is a depression. This flat plain (called Dorob) extends from the Walvisbay Lagoon towards the border with Namibia. The soil contains mainly sand and silt and a high amount of salt. Due to its low altitude (just above sea level) and its short distance from the sea, sea water seeps into the soil, and in several places salt crusts appear.

\subsubsection{Inselbergs}

Inselbergs were formed by magmatic intrusions in the Cambrium, which 
were sometimes later transected by dolorite dykes. These granite rocks, which can surface due to erosion of the surrounding (softer) material, contain, due to their morphology, a large number of habitats for plants, in crevices, gullies, depressions, cracks and at the foot of these inselbergs. Some inselbergs (e.g. Vogelfederberg) receive a considerable amount of water through fog.

\subsubsection{Swartbankberg}

This mountain belongs to a range of calcrete mountains extending northwards from the Kuiseb and crossing the Swakop (Swartbankberg, Hamilton Range or Hamiltonberge and the Witpoortberge). This entity belongs to the Karibib formation (Damara sequence, late Precambrium). Their calcium ion rich conditions, together with their height which allows the interception of fog, offers a quite different vegetation in comparison with neighbouring inselbergs (e.g. Aloe asperifolia A. BERGER is a typical plant for these mountains).

\subsubsection{Sand Sea of the Southern Namib}

This dune area extends from the Kuiseb, southwards to Lüderitz.

Along the coast, between Sandwich Bay and Walvisbay plants of salsola nollothensis AELLEN trap windblown sand. This is the first stage in the formation of the typical coastal dunes. These dunes can reach heights of more than 10 $\mathrm{m}$.

The sand sea of the Southern Namib as well as the coastal dunes were formed largely during the Quaternary. In some dune valleys older formations (mainly Tertiary) can be found: calcrete and red, partially consolidated, dune deposits. Only at a few places do intrusive rocks, of various ages, surface.

\subsection{Vegetation of the Kuiseb area}

The variation of geographical and geological entities in the Kuiseb area creates a number of very different biotopes which gives rise to a considerable diversity in plant communities.

\subsubsection{River Valley of the Kuiseb}

The riverine communities of the Kuiseb are of considerable importance to the Central Namib biome since they provide shelter and food for many species of animals. It is also the most important residential area of the Topnaar.

In the riverbed ephemeral species germinate and grow after a flood or heavy rain. The number of species occuring in a certain area of the riverbed 
in any given year is determined by the following factors:

\section{Flood:}

- Affluents of the Kuiseb coming from different regions. The species composition can be different depending on which affluents were flowing.

- The point in the riverbed where the flood stopped and deposited seeds and fruits.

- Duration of the flood. The longer the flood continues the deeper the water can penetrate into the soil of the riverbed. Sometimes the amount of water, thus drained into the soil, is too little to support the full development of seedlings.

\section{Riverbed:}

- The water-holding capacity of the soil can be a selective factor.

For complete growth and development different plants need different amounts of water.

- Availability of suitable places for germination.

\section{Grazing:}

- The game and the livestock of the Topnaar are selective consumers of germinating and growing plants. The composition of plant communities is influenced to a certain extent by the grazing habits of these animals.

The number of species occuring decreases towards the coast due to the smaller number of floods. The vegetation in the riverbed near Topnaar villages is very poor due to overgrazing.

The vegetation on and immediately above the flood mark is characterized by Nicotiana glauca Graham (an alien) and Acacia albida Del.. At some places Cladoraphis spinosa (L.F.) S.M.PHILLIPS is very abundant. Pechuel-Loeschea leubnitziae (O. KUNTZE) O. HofFm. is a regular companion in this community together with Tribulus zeyheri Sonder, Sutera maxii Hiern and Adenolobus garipensis (E.MEYer) TORRE \& Hillcoat. Downstream from Soutrivier Pechuel-Loeschea leubnitziae (O. KunTzE) O. Hoffm. forms dense stands.

Further away from the riverbed Acacia albida DeL. becomes the dominant species within the plant community, sometimes together with Tamarix usneoides E.Meyer Ex Bunge and Acacia erioloba E.Meyer. Under the tree layer Pechuel-Loeschea 
leubnitziae (O. KUntze) O. Hoffm. is the most abundant species. In some places, a single Euclea pseudobenus E. MEYER EX A.DC can be found.

Higher up, the plant community consists mainly of Acacia erioloba E.MEYER and some Acacia albida Del. together with thick stands of Salvadora persica L. Tamarix usneoides E.Meyer Ex Bunge is a regular companion. Towards the dunes the hummock forming grass Stipagrostis sabulicola (PILGER) DE WINTER, sometimes together with Salvadora persica L., becomes dominant.

The Kuiseb delta is an important biotope as it includes the greater part of the !nara fields. The delta can be divided in the southern and northern Kuiseb arm. The main !nara fields are situated in the southern Kuiseb arm. Acanthosicyos horridus Welw. ex Benthamm \& Ноoк. F. forms large hummocks. Together with Stipagrostis sabulicola (PILGER) DE WINTER, Tamarix usneoides E.MEYER EX BUNGE is characteristic for this area. In some places Acacia erioloba E.MEYER is a creeping bush and due to this, contributes to the formation of hummocks. The northern Kuiseb arm is separated from the Kuiseb river by a dam. The vegetation is composed of the same species as the southern part, but is generally in a very bad condition. Because no water can enter this area, Inara fields are dying and have been abandoned by the Topnaar. In this area capparis hereroensis SCHINZ and Aizoanthemum dinteri (SCHINZ) FrIEDrich occasionally occur.

\subsubsection{Gravel Plain of the Central Namib}

This large, flat area is almost totally devoid of plants for long periods of time. Shortly after a rain shower, however, it may change into a green carpet of, mainly, grasses. The genus stipagrostis is well represented. Most of the perennial vegetation lives in washes and small depressions.

Due to the influence of climatic factors the vegetation changes with distance from the sea. The gravel plain which is closest to the sea, receives a lot of precipitation through fog but very little through rain. Stones are covered with lichens while Arthraerua leubnitziae (KUnTZE) Schinz, Zygophyllum stapffii SchInz, and Asclepias buchenaviana ScH INZ grow in small depressions. In a zone immediately to the east, both the precipitation due to fog and rain is very low. Some perennial vegetation is limited to small washes. After a rain shower, however, a plant community dominated by grasses appears. Further east, the amount of rainfall increases. As a result, the number of species and their coverage increases. Some trees, e.g. Acacia reficiens WAWRA, Acacia erioloba E.MEYER, Parkinsonia africana SONDER and Boscia foetida SCHInz subsp. foetida, grow in washes. 


\subsubsection{Coastal Plain, South of Walvisbay}

This coastal plain, called Dorob, is a wet depression between the coastal dunes and the northern Kuiseb arm. Here vegetation consists mainly of Phrag. mites australis (CAV.) STEUDEL, Odyssea paucinervis (NEes) STAPF and Salsola nollothensis Aellen. Tamarix usneoides E. Meyer ex Bunge, Suaeda sp. and Lycium cinereum Thun B. are widely distributed and sometimes form monospecific stands.

\subsubsection{Inselbergs}

The Vogelfederberg is a small granite outcrop, about $55 \mathrm{~km}$ north of Gobabeb. It consists of two hills, up to $527 \mathrm{~m}$ in height. The smooth surface of the hills is devoid of any plant growth, except for some vegetation that occurs in crevices, gullies and depressions. Around the hills a plant community, consisting of numerous species can develop due to run off water. Aloe asperifolia A. BERGER is quite abundant here.

Mirabib is a small granite inselberg, $840 \mathrm{~m}$ high, WNW of Gobabeb. Plant communities are found in its small crevices, gullies and depressions and on the fringe of the mountain. Mesembryanthemum guerichianum PAX is quite an abundant plant on the mountain.

Southeast from the Mirabib there is a complex of small granite hills which belong to the same geological entity. In these hills a plant community consisting mainly of Sarcocaulon marlothii ENGL. persists.

\subsubsection{Swartbankberg and Hamilton Range}

The Swartbankberg $(464 \mathrm{~m})$ and the Hamilton Range $(549 \mathrm{~m})$ form a linear series of outcrops, consisting of limestone, intruded by dolorite dykes. Due to their height a lot of fog is trapped. This results in a relatively well developed vegetation, in sharp contrast to the surrounding gravel plain. Plants grow in crevices and cracks where run off water can collect. Exposed rocks are nearly completely devoid of vegetation. Aloe asperifolia A. BERGER, Trichocaulon pedicellatum SCHINZ, Sesuvium sesuvioides (FENZL.) VerdC. and Hereroa puttkamerana (DinTER \& Berger) Dinter \& Schwantes are found exclusively in the mountain's cracks and crevises.

On the other hand, Acanthosicyos horridus Welw. ex Benth Am \& Н Ноoк. F., Acacia erioloba E.MEYER, Euphorbia phylloclada BoIss., Gasania jurineifolia DC. subsp. scabra (DC.) Roessler and Pechuel-Loeschea leubnitziae (O. KUnTZE) O. HoffM. are found in the washes around the mountain.

A few kilometers southwest from the mountain Euphorbia lignosa MaRLOTH 
is quite common on a small calcrete hill (belonging to the same geological entity), near the Kuiseb (Swartbank). Citrullus ecirrhosus CogN. is quite common on the plains around the mountain.

\subsubsection{Dunes}

The sand dunes pose serious problems for the establishment of plants: instability of the loose sandy soil, low precipitation, high temperatures and high insolation (both resulting in huge evaporation). Most perennials show adaptations to these conditions through xeromorphy (reduction of the exposed leaf area: rolled, water storing or reduced leaves). The development of long taproots which can reach the water table or superficial roots extending over a relatively large area are other examples of adaptations. Most dune plants immobilize the moving sand which results in the formation of large hummocks.

The dunes on the salty plain along the coast between the lagoon of Walvisbay and Sandwich Bay are mainly covered by Salsola nollothensis Aellen. More inland Tamarix usneoides E.MEYER EX BUNGE covers whole dunes.

Most of the dunes south of the Kuiseb, are almost unvegetated: only in some places does Stipagrostis sabulicola (PILGer) De WinTER and Acanthosicyos horridus Welw. ex Bentham \& Hook. F. form large stands on the lower faces of dunes. In the interdunal depressions grasses occur. On the slipfaces towards the Kuiseb river Tamarix usneoides E.MEYER EX BUNGE and Salvadora persica L. cope with the moving sand.

In the dunes between Dorob and the northern Kuiseb arm, Stipagrostis sabulicola (Pllger) De Winter and Acanthosicyos horridus Welw. ex Benthamm \& Hook. F. are quite abundant, together with Zygophylum simplex L. and especially Trianthema hereroensis Schinz. In the depressions between the dunes Zygophyllum stapffi ScH INZ and Arthraerua leubnitziae (KunTzE) SCHinz appear.

\section{Natural Environment near Sesfontein}

The natural conditions in the residential area of the Topnaar of Sesfontein differ quite a lot from the conditions in the Kuiseb area. The Topnaar live on the alluvial plain of Sesfontein, north of the Hoanib river, on the fringes of the Northern Namib.

\subsection{Climate}

The climate around Sesfontein is characterized by a higher rainfall than 
in the Kuiseb area. Rainfall is, however, very irregular. Fog is rare. Temperature records are not available.

\subsection{Geography and Geology}

\subsubsection{Hoanib}

South of Sesfontein, an ephemeral river, the Hoanib, intersects the plain. The Hoanib is the primary boundary between Kaokoveld to its north and Damaraland in the south. The Hoanib is very important for the vegetation that occurs along its linear oasis which attracts a lot of game. The source of the river is situated west of Kamanjab on the central Namibian plateau. A large part of the catchment area is situated in the central part of Kaokoveld and Damaraland. A mean annual precipitation of $100-250 \mathrm{~mm}$ in this area is sufficient to yield some superficial waterflow during the rainy season. Downstream it forms a deep gorge (the Khowarib Schlucht) before it successively enters the plains of Warmquelle, Sesfontein and OmaruruOkambonde-Okongoro. From there on, the river forms a deep gorge towards Amspoort. While the plains are used as grazing grounds by the livestock of Damara, Topnaar, Herero and Himba; the gorge is an important grazing ground and water source for a lot of game, including elephants, rhinos and giraffes. Downstream of Amspoort the Hoanib riverbed widens and forms a large vlei (swamp) called Gui-uin. The lower Hoanib, downstream of Gui-uin is completely covered by dunes for about $15 \mathrm{~km}$. There is no superficial waterflow downstream of Gui-uin but the subterranean waterflow is considerable. The water supplied by the Hoanib evaporates in the vlei, thus increasing the soil salinity. This results in a

deterioration of the vegetation or a salt-tolerant vegetation consisting of halophytes.

\subsubsection{Plains of Sesfontein}

Around Sesfontein there are some large alluvial plains: Giribes (WNW of Sesfontein), Omaruru-Okambonde-Okongoro (SW of Sesfontein), Sesfontein, Warmquelle (seperated from the Sesfontein plain by the Nameb-Gomgurib mountains).

\subsubsection{Mountain Ranges}

The area around Sesfontein, Warmquelle and southwards to Khoraxa-ams belongs to the latest formation of the Damara sequence which is about 650 million years old and consists of phyllite, quartzite, schist and conglomerate. 
The Nameb-Gomgurib mountain range as well as the mountains north of Sesfontein, east and south of Warmquelle are older (based on relative datings) and consist of dolomite, limestone, shale and chert. The Nameb-Gomgurib mountain range is north-south orientated, perpendicular to the Hoanib. It separates the plains of Sesfontein and Warmquelle and has a height of 1325 $\mathrm{m}$.

\subsection{Vegetation of Sesfontein}

\subsubsection{Hoanib}

The Hoanib river flows through a narrow gorge between Sesfontein and Amspoort.

The Gui-uin Vlei is completely covered by Suaeda cfr. plumosa Aellen and Tamarix usneoides E.Meyer ex Bunge. At some places, Nicotiana glauca Graham and Ficus sycomorus L. can be found.

\subsubsection{Plains of Sesfontein}

The sandy plain of Sesfontein is covered with a plant community dominated by acacta tortlis (ForssKaL) HAYNE subsp. heterocantha (BURCHELL) BRENAN and Colophospermum mopane (Kirk ex Bentham) Kirk ex Leonard.

The sandy Giribis plain, northwest of Sesfontein mainly consists of sttpagrostis uniplumis (Licht. eX ROEMER \& SCHULTES) De WINTER and Stipagrostis glessit Kers. Further north a stand of Commiphoragiessi VAN Der Walt and Colophospermum mopane (KIRK EX BENTHAM) KIRK EX LEONARD was found on a gravel plain.

The Omaruru - Okambonde - Okongoro plain, southwest of Sesfontein is covered with mainly gravel and stone. The vegetation consists mainly of Colophospermum mopane (KIRK EX BENThAM) KIRK EX Leonard and Acacia tortlis (Forsskal) Hayne subsp. heterocantha (Burchell) Brenan. At several places welwitschia mirabilis HoOK.F., Commiphora giessit VAN DER WALT, Calicorema capitata (MOQ.) Hook F., Adenolobus garipensis (E.MeYer) Torre \& Hillcoat, Boscta foetida Schinz subsp. foetida and Boscia albitrunca (BURCh.) GILG \& BENEDICT can be found together with Parkinsonia africana Sonder, Maerua schinzit PAX, Galenta africana L., Cleome foliosa Hоoк.F. var. foltosa and Acacta montis-ustl MerXm. \& Schreiber. 